\title{
Marine nitrogen fixation as a possible source of atmospheric water-soluble organic nitrogen aerosols in the subtropical North Pacific
}

\section{Tsukasa Dobashi}

Hokkaido University

Yuzo Miyazaki ( $\nabla$ yuzom@lowtem.hokudai.ac.jp )

Hokkaido University

Eri Tachibana

Hokkaido University

Kazutaka Takahashi

The University of Tokyo

\section{Sachiko Horii}

The University of Tokyo

\section{Yoko Iwamoto}

Hiroshima University

\section{Shu-Kuan Wong}

The University of Tokyo

Koji Hamasaki

The University of Tokyo

\section{Research Article}

Keywords: Atmospheric organic nitrogen, Marine aerosol, Nitrogen fixation, Ammonia

Posted Date: June 28th, 2022

DOI: https://doi.org/10.21203/rs.3.rs-1342180/v2

License: (c) (1) This work is licensed under a Creative Commons Attribution 4.0 International License. Read Full License 


\section{Abstract}

Water-soluble organic nitrogen (WSON) in marine atmospheric aerosols affect the water-solubility, acidity, and light-absorbing properties of aerosol particles, which are important parameters in assessing both the climate impact and the biogeochemical cycling of bioelements. Size-segregated aerosol and surface seawater (SSW) samples were simultaneously collected over the subtropical North Pacific to investigate the origin of WSON in the marine atmosphere. The fine-mode WSON concentration $\left(7.5 \pm 6.6 \mathrm{ngN} \mathrm{m}^{-3}\right)$ at $200-240^{\circ} \mathrm{E}$ along $23^{\circ} \mathrm{N}$ defined as the eastern North Pacific (ENP) was significantly higher than that $\left(2.4 \pm 1.9 \mathrm{ngN} \mathrm{m}^{-3}\right)$ at $135-200^{\circ} \mathrm{E}$, defined as the western North Pacific (WNP). Analysis of the stable carbon isotope ratio of water-soluble organic carbon (WSOC) $\left(\delta^{13} \mathrm{C}_{\mathrm{WSOC}}\right)$ together with backward trajectory indicated that most of the observed WSON in the fine particles in the ENP originated from the ocean surface. We found a significant positive correlation between the WSON concentrations and nitrogen fixation rate in SSW. The result indicates that reactive nitrogen (dissolved organic nitrogen and ammonium), produced and exuded by nitrogen-fixing microorganisms in SSW, contributed to the formation of WSON aerosols. This study provides new insights into the role of ocean-derived reactive nitrogen aerosols associated with marine microbial activity.

\section{Introduction}

Ocean-derived atmospheric organic aerosols (OAs) play an essential role in cloud formation processes and subsequently impact radiation over the open ocean (Rosenfeld et al., 2019). Therefore, it is essential to understand the formation process, composition, and emission flux of marine aerosols to assess the ocean-to-cloud relationship and its impact on climate (Oreopoulos et al., 2008; Salter et al., 2008). In addition to primary emissions of OAs (POAs), the origin and formation processes of secondary OAs (SOAs) from the ocean surface remain unclear. Brüggemann et al. (2018) indicated that additional SOAs from the oxidation of photochemically active precursors, such as volatile organic compounds (VOCs) from the ocean surface, are important, especially in tropical/subtropical regions with low POA concentrations; such SOAs contribute up to $60 \%$ of additional OA mass. However, field measurements of marine SOAs have been limited.

Regarding the chemical components found in marine organic aerosols, water-soluble organic nitrogen (WSON) can affect the hygroscopicity, light-absorbing properties, and acidity of OAs as well as the global biogeochemical cycling of nitrogen (Mohr et al., 2013; van Pinxteren et al., 2017; Facchini et al., 2008; Nehir and Koçak, 2018). Miyazaki et al. (2011) demonstrated that marine organic aerosols are enriched in ON from marine biological origins in the western North Pacific. Altieri et al. (2016) also suggested the importance of a marine biogenic source of aerosol WSON in the western North Atlantic, leading to the conclusion that only $27 \%$ of total nitrogen (TN) deposition to the global ocean is anthropogenic, which is significantly less than the previously estimated values of $48-80 \%$ (Duce et al., 2008; Kanakidou et al., 2012). The ocean has been recognized to act as a source to atmospheric ON (e.g., alkyl nitrates, aliphatic amines, and urea) and ammonia $\left(\mathrm{NH}_{3}\right)$; the chemical compositions of atmospheric $\mathrm{ON}$ include a wide 
variety of functional groups (Altieri et al., 2016). However, the origin and formation process of WSON aerosols, particularly those of marine atmospheric aerosols remain unclear.

There is also substantial uncertainty in our understanding of the linkage between the formation of aerosol WSON and marine phytoplankton at the sea surface. Among the major groups of marine phytoplankton, cyanobacteria are the dominant primary producers in subtropical gyres (Rousseaux et al., 2012; Ottesen et al., 2014), which occupy one-third of Earth's surface. In particular, $\mathrm{N}_{2}$-fixing microorganisms including cyanobacteria are widely distributed in the subtropical North Pacific (Cheung et al., 2020; Zehr et al., 2020), which is a primarily oligotrophic area with a weak vertical supply of nitrate from below the euphotic layer (Shiozaki et al., 2017; Yamaguchi et al., 2021). In this oceanic region, $\mathrm{N}_{2}$ fixation by marine microorganisms such as Trichodesmium, a genus of filamentous cyanobacteria, is expected to be a possible source of reactive nitrogen in the atmosphere (Frischkorn et al., 2018). However, the effects of $\mathrm{N}_{2}$-fixing microorganisms on the sea-to-air emissions of reactive nitrogen species including WSON, have not yet been investigated.

The present study aimed to elucidate the origin and formation process of WSON aerosols in the oligotrophic subtropical ocean, particularly their linkage with $\mathrm{N}_{2}$-fixing microorganisms in surface seawater. We measured WSON and other reactive nitrogen species in size-segregated aerosols collected onboard a research vessel sailing over the subtropical North Pacific along the longitudinal transect in summer 2017. The discussion is extended to comparisons of the observed nitrogen aerosols with $\mathrm{N}_{2}$ fixation rates in SSW to investigate possible sources of WSON over the oceanic region.

\section{Experimental}

\subsection{Aerosol Sampling}

Ambient aerosol sampling was conducted from 12 August to 5 October 2017 onboard the research vessel Hakuho Maru Hashihama et al., 2020; Yamaguchi et al., 2021). Sampling was carried out during cruise $\mathrm{KH}$-17-4 from Vancouver to Tokyo via Honolulu in the subtropical North Pacific (Fig. 1). The aerosol samples were collected using a high-volume air sampler (HVAS; Model 120SL, Kimoto Electric, Osaka, Japan) located on the deck above the bridge of the ship. A cascade impactor (Cl; Model TE-234, Tisch Environmental, Cleves, OH, USA) was attached to the HVAS to collect size-segregated particles at a flow rate of $₫ 1130 \mathrm{~L} \mathrm{~min}^{-1}$, without temperature or humidity control. In the present study, we used analytical results obtained from the one bottom stage and four upper stages of the impactor, which collected particles with aerodynamic diameter $\left(D_{p}\right)<0.95 \mu \mathrm{m}$ every $24 \mathrm{~h}$ and $D_{p}>0.95 \mu \mathrm{m}$ every $48 \mathrm{~h}$, respectively. Aerosol particles collected at the bottom and upper stages were referred to as fine and coarse particles, respectively. To avoid possible contamination from ship exhaust during aerosol sampling, the sampling pump of the HVAS was shut off when the relative wind direction was out of \pm 60 degrees to the bow and/or when the relative wind speed was low $\left(<5 \mathrm{~m} \mathrm{~s}^{-1}\right)$. 
The aerosol samples were collected on quartz fiber filters $(25 \mathrm{~cm} \times 20 \mathrm{~cm})$, which were precombusted at $450^{\circ} \mathrm{C}$ for $6 \mathrm{~h}$ to remove any contaminants. Each collected filter was stored in glass jars with a Teflonlined screwed cap at $-20^{\circ} \mathrm{C}$ to limit chemical reactions on the filter and losses of volatile compounds. In this study, aerosol samples collected with a total air volume $<100 \mathrm{~m}^{3}$ were not used. In total, 51 and 9 samples are presented for the fine and coarse particles, respectively. These numbers accounted for $88 \%$ and $82 \%$ of the total numbers of fine and coarse aerosol samples collected, respectively.

\subsection{Surface seawater (SSW) sampling and chlorophyll (Chl) a analysis}

SSW samples were collected using an acid-cleaned bucket during each aerosol sampling duration. The average temperature of SSW at each sampling point was $26.1 \pm 2.1^{\circ} \mathrm{C}$. In total, analytical results of 12 SSW samples obtained along $23^{\circ} \mathrm{N}$ were shown in the present study. The SSW samples for Chl $a$ analysis were filtered using 25-mm Whatman GF/F filters (GE Healthcare, Buckinghamshire, UK). Chl a concentrations were further measured fluorometrically using 10-AU ${ }^{\mathrm{TM}}$ Field and Laboratory Fluorometer (Turner Designs, Sunnyvale, CA) after extraction with N', N'dimethylformamide (Suzuki and Ishimaru,1990).

\subsection{Chemical analysis of water-soluble aerosols}

To measure the concentrations of WSOC and WSTN in the aerosol filter samples, a filter cut of $19.63 \mathrm{~cm}^{2}$ was extracted with $15 \mathrm{~mL}$ of ultrapure water under ultrasonication and filtered using a disc filter (MillexGV, $0.22 \mu \mathrm{m}$, Millipore, Billerica, MA, USA). The concentrations of WSOC and WSTN were determined using a total organic carbon (TOC) analyzer with a TN unit (Model TOC-L $\mathrm{CHP}_{\mathrm{P}}+\mathrm{TNM}-\mathrm{L}$, SHIMADZU). Additionally, another cut of the filter $\left(7.07 \mathrm{~cm}^{2}\right)$ was extracted with $10 \mathrm{~mL}$ of ultrapure water to measure the concentrations of $\mathrm{Na}^{+}, \mathrm{NH}_{4}{ }^{+}, \mathrm{NO}_{3}{ }^{-}, \mathrm{NO}_{2}{ }^{-}$, and MSA. The same syringe filter type as described above was used, before the extract was injected into an ion chromatograph (Model 761 compact IC; Metrohm). Here the WSON concentration was defined as the difference between the WSTN and inorganic nitrogen $\left(\mathrm{NH}_{4}{ }^{+}, \mathrm{NO}_{3}{ }^{-}, \mathrm{NO}_{2}{ }^{-}\right)$concentrations.

\subsection{Stable carbon isotopic characterization of water-soluble organic aerosols}

To determine the $\delta^{13} \mathrm{C}$ of WSOC $\left(\delta^{13} \mathrm{C}_{\text {WSOC }}\right)$ in the collected aerosols, a portion of the filter $\left(9.08 \mathrm{~cm}^{2}\right)$ was extracted with $20 \mathrm{~mL}$ of ultrapure water. The extracted samples were then concentrated via rotary evaporation, and $40 \mu \mathrm{L}$ of each sample was transferred to be absorbed onto $15 \mathrm{mg}$ of precombusted Chromosorb in a precleaned tin cup. The ${ }^{13} \mathrm{C}_{\text {WSOC }}$ was then measured using an elemental analyzer (Flash 
EA 1112)/Continuous Flow Carrier Gas System (ConFlo)-Isotope Ratio Mass Spectrometer (Delta V, Thermo Finnigan) to determine the $\delta^{13} \mathrm{C}$ of WSOC $\left(\delta^{13} \mathrm{C}_{\text {Wsoc }}\right.$ ) (Miyazaki et al., 2012). The ${ }^{13} \mathrm{C}$ data were reported relative to an established reference of carbon Vienna Pee Dee Belemnite (VPDB).

\subsection{Estimation of nitrogen fixation rate}

Primary production and $\mathrm{N}_{2}$-fixation rates were determined using methods previously reported (Shiozaki et al., 2017), which followed Mohr et al. (2010) and Hama et al. (1983), respectively. The SSW samples were collected directly from an acid-cleaned bucket into acid-cleaned 4.5-L polycarbonate bottles. The SSW samples to estimate the initial ${ }^{15} \mathrm{~N}$ and ${ }^{13} \mathrm{C}$ enrichment of POM were filtered immediately onto precombusted GF/F filters. For incubation ${ }^{13} \mathrm{C}$-labeled sodium bicarbonate (99 atom\% ${ }^{13} \mathrm{C}$; Cambridge Isotope Laboratories, Inc.) was added to each duplicate bottle at a final concentration of $200 \mu \mathrm{mol} \mathrm{L}^{-1}$. The $110 \mathrm{~mL}$ of ${ }^{15} \mathrm{~N}_{2}$-enriched SSW, in which $1.1 \mathrm{ml}$ of ${ }^{15} \mathrm{~N}_{2}$ gas ( $>99$ atom\% ${ }^{15} \mathrm{~N}$, Shoko Science) was dissolved using a Sterapore membrane unit (20M1500A: Mitsubishi Rayon Co., Ltd.), was added to each bottle. The samples were then incubated for $24 \mathrm{~h}$ using an on-deck incubator with surface SSW running continuously. The incubation was terminated by gentle vacuum filtration of the SSW samples through precombusted $\mathrm{GF} / \mathrm{F}$ filters. The filters were then frozen at $-20^{\circ} \mathrm{C}$ until the post measurement on the ground. The filter samples were dried at $50^{\circ} \mathrm{C}$ in an oven and were exposed to hydrogen chloride $(\mathrm{HCl})$ fumes for $2 \mathrm{~h}$ to remove inorganic carbon, followed by being dried at $50^{\circ} \mathrm{C}$ again. The $\mathrm{N}$ and $\mathrm{C}$ contents and their stable isotope ratios were then determined using a DELTA $\vee$ advantage mass spectrometer (Thermo Electron, USA) connected to an elemental analyzer. $\mathrm{N}_{2}$-fixation activity was regarded to be significant when the atom\% of ${ }^{15} \mathrm{~N}$ for each incubated bottle was higher than that for the initial sample by 0.00146 atom\% (Montoya et al., 1996). Primary production and $\mathrm{N}_{2}$-fixation rates were determined twice at each sampling station.

\section{Longitudinal Distributions Of Wson}

Figs.2a and $\mathbf{2} \mathbf{b}$ show the longitudinal distribution of the concentrations of WSON in fine particles $\left(W_{S O N}\right)$ with particle diameter $\left(D_{P}\right)<0.95 \mu \mathrm{m}$ and in coarse particles $\left(W_{S O N}\right)$ with $D_{P}>0.95 \mu \mathrm{m}$ from samples collected at $23^{\circ} \mathrm{N}$ in the subtropical North Pacific (Fig. 1). The average concentrations of $\mathrm{WSON}_{\mathrm{F}}$ and $\mathrm{WSON}_{\mathrm{C}}$ were $6.1 \pm 6.2 \mathrm{ngN} \mathrm{m}^{-3}$ and $22 \pm 21 \mathrm{ngN} \mathrm{m}^{-3}$, respectively, during the cruise measurement. The sum of these values is within a range of the WSON concentrations in total suspended particles (TSP) collected over the western North Pacific (3.0-35 $\mathrm{ngN} \mathrm{m}^{-3}$ ) (Duce et al., 2008). Here, along the cruise track at $23^{\circ} \mathrm{N}$, the oceanic region at $200-240^{\circ} \mathrm{E}$ is defined as the eastern North Pacific (ENP), whereas the region at $135-200^{\circ} \mathrm{E}$ is defined as the western North Pacific (WNP). Concentrations of WSON both in the fine and coarse particles showed a distinct longitudinal gradient, with substantially higher concentrations in ENP. The average concentrations of $\mathrm{WSON}_{\mathrm{F}}$ and $\mathrm{WSON}_{\mathrm{C}}$ in ENP were approximately 3-6 times as large as those in the WNP (Table 1). 
The longitudinal distributions of the mass concentrations of inorganic nitrogen $\left(\mathrm{NH}_{4}{ }^{+}, \mathrm{NO}_{3}{ }^{-}\right.$, and $\left.\mathrm{NO}_{2}{ }^{-}\right)$ generally showed similar patterns to those of WSON (Fig. S1). The sum of the mass concentrations of the inorganic nitrogen in ENP was approximately twice as large as those in WNP. Overall, $\mathrm{NH}_{4}{ }^{+} \mathrm{N}$ was the dominant component of water-soluble total nitrogen (WSTN) ( 78\%) in the fine-mode aerosols, followed by WSON (16\%) (Fig. 2c). In contrast, $\mathrm{NO}_{3}{ }^{-} \mathrm{N}$ was the most abundant WSTN component of the coarsemode aerosols, which accounted for $83 \%$ of the WSTN mass on average. Notably, the mass fraction of WSON in ENP was significant, accounting for up to $₫ 50 \%$ (average: $19 \pm 15 \%$ ) and $₫ 11 \%$ of the WSTN in the fine and coarse particle masses, respectively (Figs. $\mathbf{2 c}$ and $\mathbf{2 d}$ ). This result indicates the importance of the abundance of WSON, particularly in the fine particles in ENP.

Fig. 2e presents the concentrations of chlorophyll (Chl) a in surface seawater (SSW) samples obtained during the cruise, as well as the average concentrations of Chl a during August-September 2017 derived from the MODIS-Aqua ocean color data (https://neo.sci.gsfc.nasa.gov/view.php?

datasetld=MY1DMM_CHLORA\&year=2017). The two different measurements of Chl. a generally showed similar longitudinal distributions, which resemble the longitudinal trend of the WSON concentrations. Moreover, 5-day back trajectories, calculated by HYSPLIT (https://www.ready.noaa.gov/HYSPLIT_traj.php), showed that the sampled air masses were transported primarily over the oceanic regions in the Pacific (Fig. 1). These results suggest that most of the observed aerosols were transported within the marine boundary layer with less influence from terrestrial sources prior to sampling. This is supported by the concentrations of nss- $-\mathrm{Ca}^{2+}$ and nss- $\mathrm{K}^{+}$as well as nss$\mathrm{SO}_{4}{ }^{2-}$ /methanesulfonic acid (MSA) ratios which did not show significant differences between WNP and ENP (Table 1). The overall results suggested that the observed aerosols, particularly those in ENP, were largely influenced by marine sources associated with phytoplankton.

\section{Isotopic Characterization Of Aerosol Organic Carbon And Formation Processes Of Wson}

Previously, a method using stable carbon isotope ratios $\left({ }^{13} \mathrm{C}\right)$ of aerosol organic carbon has been successfully used to determine the contributions of marine and terrestrial sources to organic aerosols in the marine atmosphere (Cachier et al., 1986; Miyazaki et al., 2016). The $\delta^{13} \mathrm{C}$ of water-soluble organic carbon (WSOC; $\delta^{13} \mathrm{C}_{\mathrm{WSOC}}$ ) as a function of the $\mathrm{WSON}_{\mathrm{F}}$ concentrations is shown in Fig. 3. The average $\delta^{13} \mathrm{C}_{\text {Wsoc }}$ observed in this study was $-22.8 \pm 1.7 \%$, with $71 \%$ of the data (12 out of 17 data points) in the range of typical marine origin (between $-24 \%$ ond $-18 \%$ o) (Miyazaki et al., 2016), while that of terrestrial origin is between $-27 \%$ and $-25 \%$ o (Cachier et al., 1986; Dasari et al., 2019). This isotopic characterization supports that most of the organic carbon fraction of the observed aerosols were of marine origin.

To elucidate the possible formation processes of the observed WSON, we used several tracers of marine origins. Figs. $\mathbf{4 a}$ and $\mathbf{4 b}$ show scatter plots between WSON and $\mathrm{Na}^{+}$concentrations. The concentrations 
of $\mathrm{Na}^{+}$, used as a tracer of marine primary emissions, did not show any significant positive correlations with those of $\mathrm{WSON}_{F}\left(R^{2}=0.04\right)$ or $\mathrm{WSON}_{C}\left(R^{2}=0.03\right)$ in the study area. Specifically, the $R^{2}$ value between $\mathrm{WSON}_{\mathrm{F}}$ and $\mathrm{Na}^{+}{ }_{\mathrm{F}}$ was 0.003 in ENP, while $\mathrm{WSON}_{\mathrm{F}}$ and $\mathrm{Na}^{+}{ }_{\mathrm{F}}$ concentrations even showed a negative correlation $\left(R^{2}=0.49\right)$ in WNP (Fig. 4a). The correlation cannot be statistically discussed for the coarse mode separately in ENP and WNP due to the limited number of data points. Nevertheless, the WSON concentration was higher in the ENP than in the WNP for the same $\mathrm{Na}^{+}$concentration level in the coarse particles (Fig. 4b), suggesting that WSON was more abundant relative to $\mathrm{Na}^{+}$in coarse particles in ENP. Moreover, concentrations of glucose, a molecular tracer of marine primary aerosols (Miyazaki et al., 2018), were below the lower detection limit for most of the samples during the cruise. These results suggest insignificant contributions of direct emissions from the sea surface to the observed WSON.

The above results also imply that secondary formation was likely the dominant process underlying the formation of WSON observed in this study. The process includes accommodation of secondary WSON onto sea salt particles. Figs. $\mathbf{4 c}$ and $\mathbf{4 d}$ present scatter plots between WSON and MSA concentrations in each particle size category. MSA has been widely used as a tracer of marine SOA because it is an oxidation product of dimethyl sulfate (DMS). MSA is either produced by gas-phase MSA directly scavenged by aerosols or rapidly produced in the aqueous phase from scavenged dimethylsulfoxide (DMSO) and methanesulfinic acid (MSIA) (Zhu et al., 2006). The concentrations of WSON did not show any significant correlations with those of MSA in each size range regardless of the oceanic region. The insignificant correlation suggests that the origin of the observed WSON aerosols differed from that of DMS or that the formation pathways of WSON were different from the oxidation processes of DMS.

\section{Distributions Of Nitrogen Fixation And Aerosol Wson}

To further explore the origin and possible formation process of the observed WSON aerosols associated with phytoplankton, we focused on $\mathrm{N}_{2}$ fixation in SSW as a possible source of atmospheric reactive nitrogen. $\mathrm{N}_{2}$ fixation is the biological conversion of $\mathrm{N}_{2}$ to $\mathrm{NH}_{4}{ }^{+}$or dissolved ON (DON), which represents the main external source of bioavailable nitrogen in marine environments. A significant fraction of fixed $\mathrm{N}_{2}$ can be directly released by $\mathrm{N}_{2}$-fixing microorganisms as dissolved inorganic nitrogen $\left(\mathrm{NH}_{4}{ }^{+}\right.$, $\mathrm{NO}_{3}{ }^{-}$, and $\mathrm{NO}_{2}{ }^{-}$) and DON in the ocean. Luo et al. (2014) estimated that on average, spatially integrated $\mathrm{N}_{2}$ fixation over the Pacific accounted for $~ 50 \%$ of that in the global ocean, pointing to the importance of the Pacific in terms of this process.

In the subtropical North Pacific, previously measured nitrogen isotope ratios $\left(\delta^{15} \mathrm{~N}\right)$ in particulate organic matter (POM) from seawater suggested that POM was significantly affected by nitrogen supplied from $\mathrm{N}_{2}$-fixing microorganisms (Horii et al., 2018). Indeed, in the current study, the average $\delta^{15} \mathrm{~N}$ of POM in the SSW samples was $-0.3 \pm 1.0 \%$ (data not shown), which is within the range of $\delta^{15} \mathrm{~N}$ values of diazotrophic cyanobacteria typically ranging from $-2 \%$ to $0 \%$ (Horii et al., 2018). This indicates that 
the organic matter in SSW collected in the study region is derived from nitrogen supplied by $\mathrm{N}_{2}$ fixing microorganisms such as cyanobacteria.

Fig. 5 shows the latitudinal distributions of the $\mathrm{N}_{2}$-fixation rate in the SSW samples compared with those of aerosol WSON concentrations in each size category. The average $\mathrm{N}_{2}$-fixation rate in the SSW samples collected in ENP was $38.6 \pm 13.3 \mathrm{ngN} \mathrm{L}^{-1} \mathrm{~d}^{-1}$, which was significantly higher than that in the WNP $\left(11.5 \pm 10.6 \mathrm{ngN} \mathrm{L}^{-1} \mathrm{~d}^{-1}\right)$. The observed range of the $\mathrm{N}_{2}$-fixation rate in SSW is similar to those reported for the same oceanic region in previous studies (Montoya et al., 2004; Bonnet et al., 2009; Yamaguchi et al., 2019). Moreover, the longitudinal gradient of the $\mathrm{N}_{2}$-fixation rate is similar to that along $23^{\circ} \mathrm{N}$ in the tropical Pacific, as shown by previous field measurements and model simulations (Luo et al., 2014; Dutheil et al., 2018; Wang et al., 2019; Shiozaki et al., 2018; Hashihama et al., 2020). The higher $\mathrm{N}_{2}-$ fixation rate in ENP compared to that in WNP could be attributed to the greater abundance of $\mathrm{N}_{2}$-fixing microorganisms such as Trichodesmium and a symbiotic unicellular cyanobacterium (UCYN-A) measured by quantitative polymerase chain reaction (qPCR) of nifH. In particular, the number of the nifH copy of UCYN-A in ENP was three orders of magnitude larger than that in WNP (data not shown).

The WSON concentrations in both fine and coarse particles showed positive correlations with the $\mathrm{N}_{2}$ fixation rates in the SSW samples (Figs. 5 and 6), with $\mathrm{R}^{2}$ values of $0.27(p<0.05)$ and $0.60(p<0.05)$ in the fine and coarse modes, respectively. Meanwhile, the $R^{2}$ values for the WSON concentrations and primary productivity in SSW were $0.08(p=0.24)$ and $0.58(p<0.05)$ in the fine and coarse modes, respectively (Fig. S2 and S3), which were lower than those for WSON and $\mathrm{N}_{2}$-fixation rate. The positive relation between the WSON mass concentrations and $\mathrm{N}_{2}$-fixation rate in SSW suggests that reactive nitrogen produced by $\mathrm{N}_{2}$-fixing microorganisms in SSW significantly contributed to the formation of WSON aerosols.

\section{Nitrogen Fixation As A Possible Source Of Wson In Marine Aerosols}

Previous laboratory experiments showed that DON and $\mathrm{NH}_{4}{ }^{+}$are released in seawater through $\mathrm{N}_{2}$ fixation by microorganisms known as diazotrophs (Wannicke et al., 2009; Berthelot et al., 2015). Here, we discuss mass-based N:C ratios in seawater and atmospheric aerosols. The average WSTN/WSOC ratio in all the size ranges of the observed aerosols was $1.70 \pm 0.94$, while those in ENP and WNP were $1.61 \pm 0.99$ and $1.87 \pm 0.82$, respectively. It is noted that there may be bias in the WSTN:WSOC ratios particularly in WNP, because the WSOC concentrations were below the detection limit in many samples (Table S1). YvonDurocher et al. (2015) reported that the $\mathrm{N}: \mathrm{C}$ ratios of marine algal assemblages over the subtropical Pacific ranged between 0.10 and 0.13 , while Wannicke et al. (2009) obtained N:C ratios of

Trichodesmium $(0.21 \pm 0.02)$ through a laboratory experiment. Furthermore, Berthelot et al. (2015) reported that the ratio of dissolved nitrogen (DN) to DOC released during $\mathrm{N}_{2}$ fixation was $0.07 \pm 0.48$. The currently observed WSTN:WSOC ratio in the aerosols was much higher than the $\mathrm{N}: \mathrm{C}$ ratios of microbes and the DN:DOC ratios in seawater affected by $\mathrm{N}_{2}$ fixation. The higher WSTN:WSOC ratios in aerosols relative to 
the typical DN:DOC ratios in seawater suggest that nitrogen-containing aerosols are preferentially produced relative to organic carbon in the atmosphere.

Previous studies showed that oceanic regions at low latitudes, including the subtropics act as a source of $\mathrm{NH}_{3}$ (the net flux of $\mathrm{NH}_{3}$ is out of the ocean to the atmosphere) (Jickells et al., 2003; Johnson et al., 2008). Paulot et al. (2015) used two global ocean biogeochemical models to show evidence for a missing source of atmospheric ammonia $\left(\mathrm{NH}_{3}\right.$ and $\left.\mathrm{NH}_{4}{ }^{+}\right)$over the equatorial Pacific that was attributable to photolysis of marine $\mathrm{ON}$ at the ocean surface or in the atmosphere. Indeed, $\mathrm{NH}_{4}{ }^{+}$was the dominant component of the aerosol reactive nitrogen in the fine particles (Fig.2c) in this study, whereas the correlations between $\mathrm{NH}_{4}{ }^{+}$concentrations and $\mathrm{N}_{2}$-fixation rates were insignificant $\left(\mathrm{R}^{2}=0.06\right)$. This insignificant correlation is partially attributable to phase partitioning of ammonia into the gas phase in the subtropical region. The secondary formation processes of WSON include emissions of gas-phase ON from the ocean and/or marine VOCs reacting with $\mathrm{NH}_{3}$ (Paulot et al., 2015; Altieri et al., 2021), although the exact mechanism of the formation is not apparent in this study. Nevertheless, the current results of the shipboard measurements suggest that $\mathrm{N}_{2}$ fixation in SSW could partly explain one of the missing sources of atmospheric WSON and ammonia indicated by previous modeling studies.

To summarize, the current result suggests that $\mathrm{N}_{2}$-fixing microorganisms in the SSW likely contributed to the formation of aerosol WSON and possibly other reactive nitrogen species, such as $\mathrm{NH}_{3} / \mathrm{NH}_{4}{ }^{+}$, in the oceanic region of this study. Further field studies are required to elucidate the effect of $\mathrm{N}_{2}$ fixation in surface seawater on the emission of atmospheric reactive nitrogen in different oceanic regions. Additional laboratory studies are needed to evaluate the factors controlling the atmospheric emissions of reactive nitrogen associated with $\mathrm{N}_{2}$ fixation in surface sea water. Jiang et al. (2018) predicted that global ocean warming in the future would result in large increases in growth and $\mathrm{N}_{2}$ fixation by Trichodesmium. Consequently, the formation process and the amount of atmospheric WSON associated with $\mathrm{N}_{2}$ fixation in surface seawater are expected to change, which should be important from the viewpoints of the climate effect of marine atmospheric aerosols as well as the air-sea exchange of nitrogen.

\section{Conclusions}

This study investigated the origin and formation process of WSON aerosols in the oligotrophic subtropical North Pacific, in terms of their linkage with $\mathrm{N}_{2}$-fixing microorganisms in SSW, based on the cruise measurements. The average concentration of WSON in fine-mode aerosols along $23^{\circ} \mathrm{N}$ in the eastern North Pacific $\left(7.5 \pm 6.6 \mathrm{ngN} \mathrm{m}^{-3}\right)$ was much higher than that in the western North Pacific $(2.4 \pm 1.9$ $\mathrm{ngN} \mathrm{m}{ }^{-3}$ ) during the research cruise. The stable carbon isotope ratio of WSOC together with backward trajectories indicated that most of the observed WSON in the fine particles in the eastern North Pacific originated from the ocean surface. Relations of the concentrations of WSON with those of $\mathrm{Na}^{+}$and MSA imply that secondary formation, that differed from the oxidation processes of DMS, was likely the dominant process underlying the formation of WSON observed in this study. Instead, a significant 
positive correlation was found between the WSON concentrations and nitrogen fixation rate in SSW. The result indicates that reactive nitrogen, such as dissolved organic nitrogen and ammonium, produced and exuded by nitrogen-fixing microorganisms in SSW, likely contributed to the formation of WSON aerosols over the oceanic region. This study provides new implications for the role of marine microbial activity in the formation of reactive nitrogen aerosols in the ocean surface.

\section{Declarations}

\section{Data availability.}

All data used in this study are provided in the supplement.

Author contributions.

Y.M. designed and led the overall research. T.D. and Y.M. wrote the manuscript. T.D., E.T., and Y. M. performed the measurements of chemical parameters in the aerosol samples. K.T., S.H., Y.I., and K.H. collected the samples. S-K.W. and K.H. measured chlorophyll a concentration. S.H. and K. T. measured nitrogen fixation rate and $\delta^{15} \mathrm{~N}$ of POM. T.D., Y.M. and E.T. analyzed the data.

Competing interests.

The authors declare that they have no conflict of interest.

Acknowledgements.

We thank the researchers and crew of the R/V Hakuho Maru for their help with the observations. This research was supported by Grants-in-Aid for Scientific Research $(16 \mathrm{HO} 2931,19 \mathrm{H} 04233,24121005)$ from the Ministry of Education, Culture, Sports, Science and Technology (MEXT), Japan. R. Yamaguchi is acknowledged for his help with the aerosol sampling. This study was also supported by the Grant for Joint Research Program of the Institute of Low Temperature Science, Hokkaido University.

\section{References}

Altieri, K. E., Fawcett, S. E., Peters, A. J., Sigman, D. M., and Hastings, M. G.: Marine biogenic source of atmospheric organic nitrogen in the subtropical North Atlantic, Proc. Natl. Acad. Sci. U.S.A., 113, 925930, https://doi.org/10.1073/pnas.1516847113, 2016.

Altieri, K.E., Fawcett, S.E., and Hastings, M.G.: Reactive Nitrogen Cycling in the Atmosphere and Ocean, Annu. Rev. Earth Planet. Sci., 49, 523-550, https://doi.org/10.1146/annurev-earth-083120-052147, 2021.

Berthelot, H., Bonnet, S., Camps, M., Grosso, O., and Moutin, T.: Assessment of the dinitrogen released as ammonium and dissolved organic nitrogen by unicellular and filamentous marine diazotrophic 
cyanobacteria grown in culture, Front Mar Sci, 2, https://doi.org/10.3389/fmars.2015.00080, 2015.

Bonnet, S., Biegala, I. C., Dutrieux, P., Slemons, L. O., and Capone, D. G.: Nitrogen fixation in the western equatorial Pacific: rates, diazotrophic cyanobacterial size class distribution, and biogeochemical significance, Glob. Biogeochem Cycles, 23, GB3012, https://doi.org/10.1029/2008GB003439, 2009.

Brüggemann, M., Hayeck, N. and George, C.: Interfacial photochemistry at the ocean surface is a global source of organic vapors and aerosols, Nat. Commun., 9(1), 1-8, doi:10.1038/s41467-018-04528-7, 2018.

Cachier, H., Buat-Ménard, M. P., Fontugne, M., and Chesselet, R.: Long-range transport of continentally derived particulate carbon in the marine atmosphere: evidence from stable isotope studies, Tellus, 38, 161-177, https://doi.org/10.1111/j.1600-0889.1986.tb00184.x, 1986.

Cheung, S., Nitanai, R., Tsurumoto, C., Endo, H., Nakaoka, S., Cheah, W., Lorda, J.F., Xia, X., Liu, H. and Suzuki, K.: Physical forcing controls the basin-scale occurrence of nitrogen-fixing organisms in the North Pacific Ocean, Global Biogeochemical Cycles, 34, e2019GB006452, https://doi.org/10.1029/2019GB006452, 2020.

Dasari, S., Andersson, A., Bikkina, S., Holmstrand, H., Budhavant, K., Satheesh, S., Asmi, E., Kesti, J., Backman, J., Salam, A., Bisht, D. S., Tiwari, S., Hameed, Z., and Gustafsson, Ö.: Photochemical degradation affects the light absorption of water-soluble brown carbon in the South Asian outflow, Sci. Adv., 5, eaau8066, https://10.1126/sciadv.aau8066, 2019.

Duce, R.A., LaRoche, J., Altieri, K., Arrigo, K.R., Baker, A.R., Capone, D.G., Cornell, S., Dentener, F., Galloway, J., Ganeshram, R.S., Geider, R.J., Jickells, T., Kuypers, M.M., Langlois, R., Liss, P.S., Liu, S.M., Middelburg, J.J., Moore, C.M., Nickovic, S., Oschlies, A., Pedersen, T., Prospero, J., Schlitzer, R., Seitzinger, S., Sorensen, L.L., Uematsu, M., Ulloa, O., Voss, M., Ward, B., Zamora, L.: Impacts of atmospheric anthropogenic nitrogen on the open ocean, Science, 320, 893-897, https://doi.org/10.1126/science.1150369, 2008.

Dutheil, C., Aumont, O., Gorguès, T., Lorrain, A., Bonnet, S., Rodier, M., Dupouy, C., Shiozaki, T., and Menkes, C.: Modelling $\mathrm{N}_{2}$ fixation related to Trichodesmium $\mathrm{sp}$.: Driving processes and impacts on primary production in the tropical Pacific Ocean, Biogeosciences, 15(14), 4333-4352, https://doi.org/10.5194/bg-15-4333-2018, 2018.

Facchini, M.C., Decesari, S., Rinaldi, M., Carbone, C., Finessi, E., Mircea, M., Fuzzi, S., Moretti, F., Tagliavini, E., Ceburnis, D., and O'Dowd, C.D.: Important Source of Marine Secondary Organic Aerosol from Biogenic Amines, Environ, Sci. Technol., 42, 9116-9121, https://doi.org/10.1021/es8018385, 2008.

Frischkorn, K. R., Haley, S. T., Dyhrman, S. T.: Coordinated gene expression between Trichodesmium and its microbiome over day-night cycles in the North Pacific Subtropical Gyre, ISME Journal, 12, 997-1007, https://doi.org/10.1038/s41396-017-0041-5, 2018. 
Hama, T., Miyazaki, T., Ogawa, Y., Iwakuma, T., Takahashi, M., Otsuki, A., and Ichimura, S.: Measurement of photosynthetic production of a marine phytoplankton population using a stable 13C isotope, Mar. Biol, 73, 31-36, https://doi.org/10.1007/BF00396282, 1983.

Hashihama, F., Saito, H., Shiozaki, T., Ehama, M., Suwa, S., Sugiyama, T., Kato, H., Kanda, J., Sato, M., Kodama, T., Yamaguchi, T., Horii, S., Tanita., I, Takino, S., Takahashi, K., and Ogawa, H.: Biogeochemical controls of particulate phosphorus distribution across the oligotrophic subtropical Pacific ocean, Glob. Biogeochem. Cycles, 34, e2020GB006669, https://doi.org/10.1029/2020GB006669, 2020.

Horii, S., Takahashi, K., Shiozaki, T., Hashihama, F., and Furuya ,K.: Stable isotopic evidence for differential contribution of diazotrophs to the epipelagic grazing food chain in the mid-Pacific Ocean, Global Ecol. Biogeogr., 27, 1467-1480, https://doi.org/10.1111/geb.12823, 2018.

Jiang, H. B., Fu, F. X., Rivero-Calle, S., Levine, N. M., Sañudo-Wilhelmy, S. A., Qu, P. P., Wang, X. W., PinedoGonzalez, P., Zhu, Z., and Hutchins, D. A.: Ocean warming alleviates iron limitation of marine nitrogen fixation, Nature Climate Change, 8, 709-712, https://doi.org/10.1038/s41558-018-0216-8, 2018.

Jickells, T. D., Kelly, S. D., Baker, A. R., Biswas, K., Dennis, P. F., Spokes, L. J., Witt, M., and Yeatman, S. G.: Isotopic evidence for a marine ammonia source, Geophys. Res. Lett., 30, 1374, https://doi.org/10.1029/2002GL016728, 2003.

Johnson, M. T., Liss, P. S., Bell, T. G., Lesworth, T. J., Baker, A. R., Hind, A. J., Jickells, T. D., Biswas, K. F., Woodward, E. M. S., and Gibb, S. W.: Field observations of the ocean-atmosphere exchange of ammonia: Fundamental importance of temperature as revealed by a comparison of high and low latitudes, Global Biogeochemical Cycles, 22, GB1019, https://doi.org/10.1029/2007GB003039, 2008.

Kanakidou, M., Duce, R. A., Prospero, J. M., Baker, A. R., Benitez-Nelson, C., Dentener, F. J., Hunter, K. A., Liss, P. S., Mahowald, N., Okin, G. S., Sarin, M., Tsigaridis, K., Uematsu, M., Zamora, L. M., Zhu, T.: Atmospheric fluxes of organic $N$ and $P$ to the global ocean, Global Biogeochem Cycles, 26, GB3026, https://doi.org/10.1029/2011GB004277, 2012.

Luo, Y. W., Lima, I. D., Karl, D. M., Deutsch, C. A. and Doney, S. C.: Data-based assessment of environmental controls on global marine nitrogen fixation, Biogeosciences, 11, 691-708, https://doi.org/10.5194/bg-11-691-2014, 2014.

Miyazaki, Y., Kawamura, K., Jung, J., Furutani, H., and Uematsu, M.: Latitudinal distributions of organic nitrogen and organic carbon in marine aerosols over the western North Pacific, Atmos. Chem. Phys., 11, 3037-3049, https://doi.org/10.5194/acp-11-3037-2011, 2011.

Miyazaki, Y., P.Q. Fu, Kawamura, K., Mizoguchi, Y., and Yamanoi, K.: Seasonal variations of stable carbon isotopic composition and biogenic tracer compounds of water-soluble organic aerosols in a deciduous forest, Atmos. Chem. Phys., 12, 1367-1376, https://doi.org/10.5194/acp-12-1367-2012, 2012. 
Miyazaki, Y., Coburn, S., Ono, K., Ho, D. T., Pierce, R. B., Kawamura, K., and Volkamer, R.: Contribution of dissolved organic matter to submicron water- soluble organic aerosols in the marine boundary layer over the eastern equatorial Pacific, Atmos. Chem. Phys., 16, 7695-7707, https://doi.org/10.5194/acp-167695-2016, 2016.

Miyazaki, Y., Yamashita, Y., Kawana, K., Tachibana, E., Kagami,S., Mochida, M., Suzuki, K. and Nishioka, J.: Chemical transfer of dissolved organic matter from surface seawater to sea spray water-soluble organic aerosol in the marine atmosphere, Sci. Rep., 8, 14861, https://doi.org/10.1038/s41598-01832864-7, 2018.

Mohr, W., Großkopf, T., Wallace, D. W. R., and Laroche, J.: Methodological underestimation of oceanic nitrogen fixation rates, PLoS ONE, 5, https://doi.org/10.1371/journal.pone.0012583, 2010.

Mohr, C., Lopez-Hilfiker, F. D., Zotter, P., Prévôt, A. S. H., Xu, L., Ng, N. L., Herndon, S. C., Williams, L. R., Franklin J. P., Zahniser, M. S., Worsnop, D. R., Knighton, W. B., Aiken, A. C., Gorkowski, K. J., Dubey M. K., Allan J. D., and Thornton, J. A.: Contribution of nitrated phenols to wood burning brown carbon light absorption in Detling, United Kingdom during wintertime, Environ. Sci. Technol., 47, 6316-6324, https://doi.org/10.1021/es400683v, 2013.

Montoya, J. P., Voss, M., Kaehler, P. and Capone, D. G.: A simple, high precision, high sensitivity tracer assay for dinitrogen fixation, Appl, Environ. Microbiol, 62, 986-993, https://doi.org/10.1128/AEM.62.3.986-993.1996, 1996.

Montoya, J. P., Holl, C. M., Zehr, J. P., Hansen, A., Villareal, T. A. and Capone, D. G.: High rates of $\mathrm{N}_{2}$ fixation by unicellular diazotrophs in the oligotrophic Pacific Ocean, Nature, 430, 1027-1032, https://doi.org/10.1038/nature02824, 2004.

Nehir, M. and Koçak, M.: Atmospheric water-soluble organic nitrogen (WSON) in the eastern Mediterranean: origin and ramifications regarding marine productivity, Atmos. Chem. Phys., 18, 36033618, https://doi.org/10.5194/acp-18-3603-2018, 2018.

Oreopoulos, L., and Platnick, S.: Radiative susceptibility of cloudy atmospheres to droplet number perturbations. II. Global analysis from MODIS, J. Geophys. Res., 113, D14S21, https://doi.org/10.1029/2007JD009655, 2008.

Ottesen, E. A., Young, C. R., Gifford, S. M., Eppley, J. M., Marin, R. 3rd, Schuster, S. C., Scholin, C. A. and DeLong, E. F.: Ocean microbes. Multispecies diel transcriptional oscillations in open ocean heterotrophic bacterial assemblages, Science, 345, 207-212, https://doi.org/10.1126/science.1252476, 2014.

Paulot, F., Jacob, D. J., Johnson, M. T., Bell, T. G., Baker, A. R., Keene, W. C., Lima, I. D., Doney, S. C., and Stock, C. A.: Global oceanic emission of ammonia: Constraints from seawater and atmospheric observations, Global Biogeochem. Cycles, 29, 1165-1178, https://doi.org/10.1002/2015GB005106, 2015. 
Rosenfeld, D., Zhu, Y. N., Wang, M. H., Zheng, Y. T., Goren, T., and Yu, S. C.: Aerosol-driven droplet concentrations dominate coverage and water of oceanic low level clouds, Science, 363, eaav0566, https://doi.org/10.1126/science.aav0566, 2019.

Rousseaux, C. S., and Gregg, W. W.: Climate variability and phytoplankton composition in the Pacific Ocean, J. Geophys. Res., 117, C10006, https://doi.org/10.1029/2012JC008083, 2012.

Salter, S., Sortino, G., and Latham, J.: Sea-going hardware for the cloud albedo method of reversing global warming, Philos. T. Roy. Soc. A, 366, 3989-4006, https://doi.org/10.1098/rsta.2008.0136, 2008.

Shiozaki, T., Bombar, D., Riemann, L., Hashihama, F., Takeda, S., Yamaguchi, T., Ehoma, M., Hamasaki, K., Furuya, K.: Basin scale variablity of active diazotrophs and nitrogen fixation in the North Pacific, from the tropics to the subarctic Bering Sea, Global Biogeochemical Cycles, 31, 996-1009, https://doi.org/10.1002/2017GB005681, 2017.

Shiozaki, T., Bombar, D., Riemann, L., Sato, M., Hashihama, F., Kodama, T., Tanita, I., Takeda, S., Saito, H., Hamasaki, K., Furuya, K.: Linkage between dinitrogen fixation and primary production in the oligotrophic South Pacific Ocean, Global Biogeochemical Cycles, 32, 1028-1044, https://doi.org/10.1029/2017GB005869, 2018.

Suzuki, R. and Ishimaru, T.: An improved method for the determination of phytoplankton chlorophyll using N, N-dimethylformamide, J. Oceanog., 46(4):190-194, https://doi.org/10.007/BF02125580, 1990.

van Pinxteren, M., Barthel, S., Fomba, K. W., Müller, K., von Tümpling, W., and Herrmann, H.: The influence of environmental drivers on the enrichment of organic carbon in the sea surface microlayer and in submicron aerosol particles-Measurements from the Atlantic Ocean, Elementa Science of the Anthropocene, 5, 35, https://doi.org/10.1525/elementa.225, 2017.

Wang, W. L., Moore, J. K., Martiny, A. C., and Primeau, F. W.: Convergent estimates of marine nitrogen fixation, Nature, 566, 205-211, https://doi.org/10.1038/s41586-019-0911-2, 2019.

Wannicke, N., Koch, B. P., and Voss, M.: Release of fixed $\mathrm{N}_{2}$ and $\mathrm{C}$ as dissolved compounds by Trichodesmium erythreum and Nodularia spumigena under the influence of high light and high nutrient (P), Aquat Microb Ecol, 57, 175-189, https://doi.org/10.3354/ame01343, 2009.

Yamaguchi, T., Sato, M., Hashihama, F., Ehama, M., Shiozaki, T., Takahashi, K., and Furuya, K.: Basin-scale variations in labile dissolved phosphoric monoesters and diesters in the central North Pacific Ocean, J. Geophys. Res.: Oceans, 124, 3058-3072, https://doi.org/10.1029/2018jc014763, 2019.

Yamaguchi, T., Sato, M., Hashihama, F., Kato, H., Sugiyama, T., Ogawa, H., Takahashi, K., and Furuya, K.: Longitudinal and vertical variations of dissolved labile phosphoric monoesters and diesters in the subtropical North Pacific, Front. Microbiol., 11, 570081, https://doi.org/10.3389/fmicb.2020.570081, 2021. 
Yvon-Durocher, G., Dossena, M., Trimmer, M., Woodward, G., and Allen, A. P.: Temperature and the biogeography of algal stoichiometry, Global Ecology and Biogeography, 24, 562-570, https://doi.org/10.1111/geb.12280, 2015.

Zehr, J. P. and Capone, D. G.: Changing perspectives on nitrogen fixation, Science, 368, eaay9514, https://doi.org/10.1126/science.aay9514, 2020.

Zhu, L., Nenes, A., Wine, P. H., and Nicovich, J. M.: Effects of aqueous organosulfur chemistry on particulate methanesulfonate to nonsea salt sulfate ratios in the marine atmosphere, J. Geophys. Res. 111, D05316, https://doi.org/10.1029/2005JD006326, 2006.

\section{Tables}

Table 1: Average concentrations of nitrogen species and stable carbon isotope ratios in the fine $\left(D_{p}<0.95 \mu \mathrm{m}\right)$ and coarse $\left(D_{p}>0.95 \mu \mathrm{m}\right)$ aerosol particles collected along 23N in each oceanic region.

\begin{tabular}{|c|c|c|c|c|c|c|}
\hline & \multicolumn{2}{|c|}{$\begin{array}{l}\text { The western North Pacific } \\
\text { (WNP, 135-200ㅌ) }\end{array}$} & \multicolumn{2}{|c|}{$\begin{array}{l}\text { The eastern North Pacific } \\
\text { (ENP, 200-240ㅌ) }\end{array}$} & \multicolumn{2}{|c|}{ All (135-240트) } \\
\hline & Fine & Coarse & Fine & Coarse & Fine & Coarse \\
\hline $\begin{array}{c}\text { WSON } \\
\left(\mathrm{ngN} \mathrm{m}^{-3}\right)\end{array}$ & $2.4 \pm 1.9$ & $7.9 \pm 6.0$ & $7.5 \pm 6.6$ & $49.0 \pm 12.6$ & $6.1 \pm 6.2$ & $21.6 \pm 21.3$ \\
\hline $\begin{array}{c}\mathrm{NH}_{4}^{+} \\
\left(\mathrm{ngN} \mathrm{m}^{-3}\right)\end{array}$ & $42.6 \pm 15.8$ & $3.6 \pm 3.2$ & $35.5 \pm 22.2$ & $17.5 \pm 8.3$ & $37.4 \pm 20.9$ & $8.3 \pm 8.5$ \\
\hline $\begin{array}{c}\mathrm{NO}_{3}^{-} \\
\left(\mathrm{ngN} \mathrm{m}^{-3}\right)\end{array}$ & $0.5 \pm 0.4$ & $154.6 \pm 65.8$ & $1.8 \pm 1.8$ & $373.2 \pm 91.1$ & $1.5 \pm 1.7$ & $227.5 \pm 127.6$ \\
\hline $\begin{array}{c}\mathrm{NO}_{2}^{-} \\
\left(\mathrm{ngN} \mathrm{m}^{-3}\right)\end{array}$ & $0.4 \pm 0.2$ & $32.9 \pm 54.0$ & $1.4 \pm 1.4$ & $9.4 \pm 9.4$ & $1.1 \pm 1.3$ & $25.0 \pm 45.8$ \\
\hline $\begin{array}{l}\text { nss-Ca }{ }^{2+} \\
\left(\mathrm{ng} \mathrm{m}^{-3}\right)\end{array}$ & $1.6 \pm 1.5$ & $166.4 \pm 81.5$ & $0.4 \pm 1.1$ & $211.8 \pm 4.3$ & $0.7 \pm 1.3$ & $181.5 \pm 69.9$ \\
\hline $\begin{array}{c}\mathrm{nss}-\mathrm{K}^{+} \\
\left(\mathrm{ng} \mathrm{m}^{-3}\right)\end{array}$ & $5.2 \pm 4.8$ & $120.5 \pm 60.7$ & $3.9 \pm 3.0$ & $141.8 \pm 9.9$ & $4.2 \pm 3.6$ & $127.6 \pm 50.9$ \\
\hline $\mathrm{SO}_{4}{ }^{2-} / \mathrm{MSA}$ & $5.5 \pm 3.6$ & $11.4 \pm 3.5$ & $4.7 \pm 7.2$ & $19.5 \pm 10.6$ & $4.9 \pm 6.4$ & $14.1 \pm 7.8$ \\
\hline $\begin{array}{c}\delta^{13} \mathrm{C}_{\text {WSOC }} \\
(\% \text { o })\end{array}$ & $-23.9 \pm 1.4$ & NA & $-22.1 \pm 1.6$ & NA & $-22.8 \pm 1.7$ & NA \\
\hline
\end{tabular}

\section{Figures}


(a)

August 2017

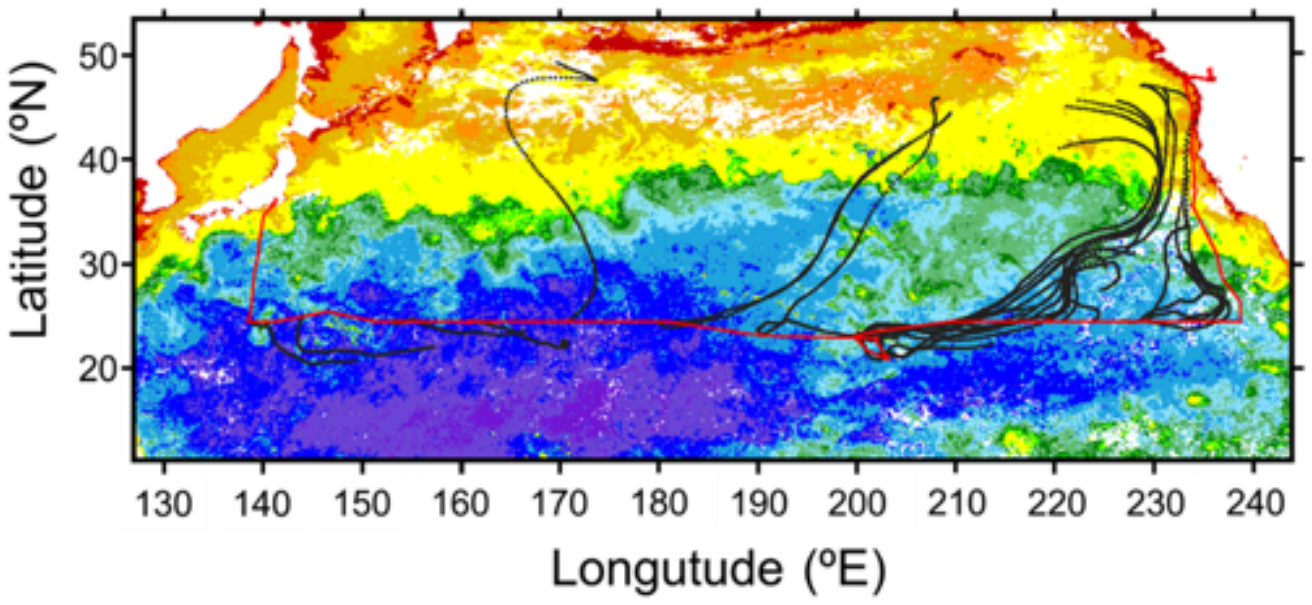

(b)

September 2017
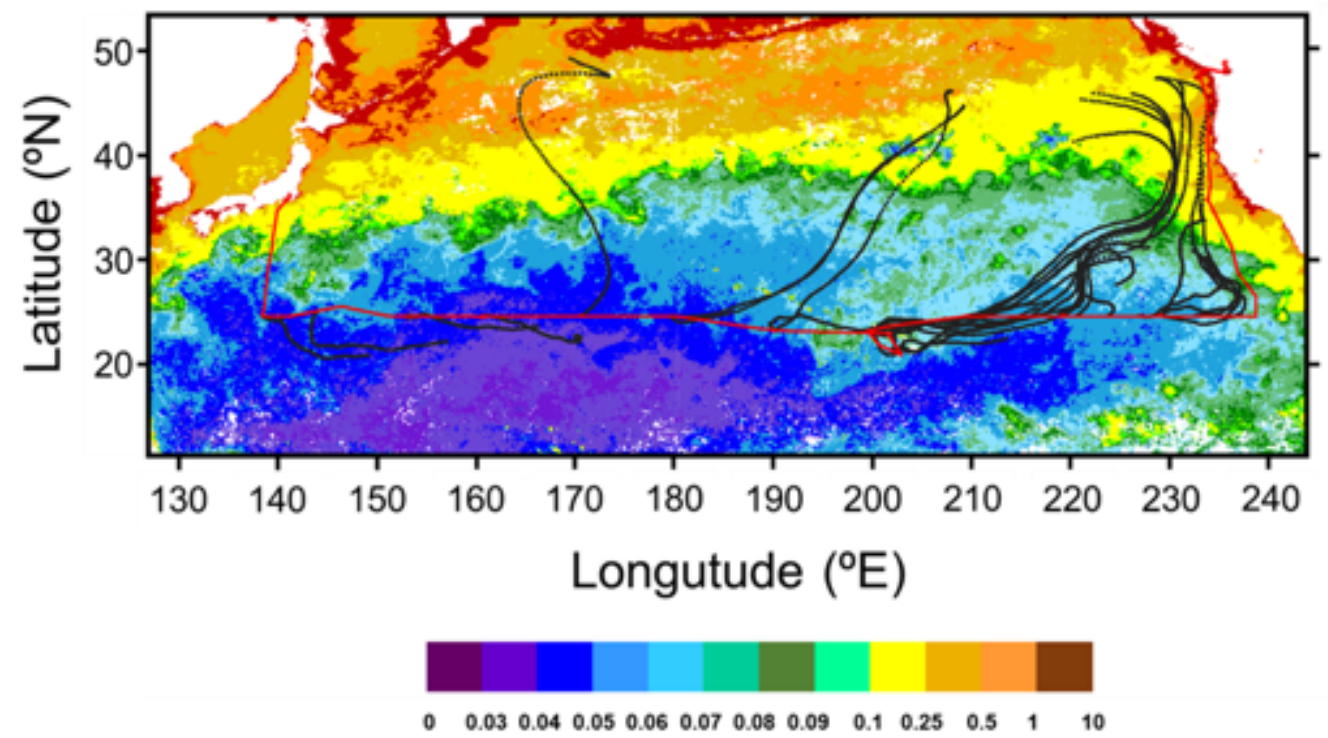

Chlorophyll a concentration $\left(\mathrm{mg} \mathrm{m}^{-3}\right)$

Figure 1

R/V Hakuho cruise track in the subtropical North Pacific between 12 August and 5 October 2017 (red), together with typical 5-day back trajectories (black). Also shown are monthly averaged concentrations of chl a for (a) August and (b) September 2017 derived from the MODIS-Aqua (https://neo.sci.gsfc.nasa.gov/view.php?datasetld=MY1DMM_CHLORA\&year=2017). Area in which data is missing is shown in white.

Figure 2 
Longitudinal distributions of each parameter of the atmospheric aerosols and surface seawater along $23^{\circ} \mathrm{N}$; the mass concentrations of WSON in (a) fine particles $\left(\mathrm{WSON}_{\mathrm{F}}\right)$ and (b) coarse particles $\left(\mathrm{WSON}_{\mathrm{C}}\right)$; the chemical mass fractions of nitrogen species in (c) $\mathrm{WSON}_{\mathrm{F}}$ and (d) $\mathrm{WSON}_{\mathrm{C}}$; (e) Chl a concentrations in the surface seawater samples during the cruise (red) and the average Chl a concentrations from AugustSeptember 2017, as measured by MODIS-Aqua (blue). WNP and ENP denote the oceanic regions of the western North Pacific and eastern North Pacific, respectively, defined in this study.

Figure 3

$\delta^{13} \mathrm{C}$ of WSOC $\left(\delta^{13} \mathrm{C}_{\mathrm{WSOC}}\right)$ as a function of the concentrations of $\mathrm{WSON}_{\mathrm{F}}$. Solid and open circles indicate the data of the eastern North Pacific (ENP; $200-240^{\circ} \mathrm{E}$ ) and the western North Pacific (WNP; $\left.135-200^{\circ} \mathrm{E}\right)$, respectively.

(a)

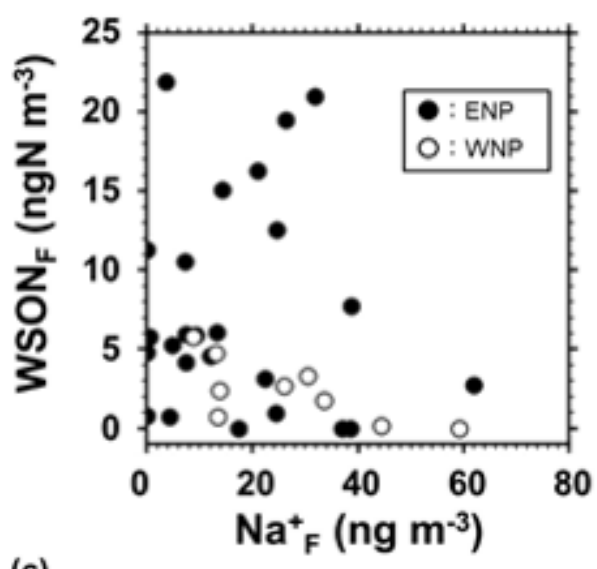

(c)

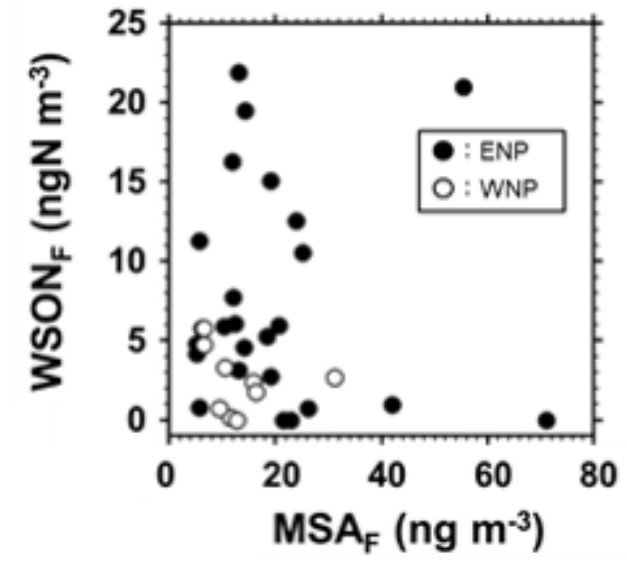

(b)

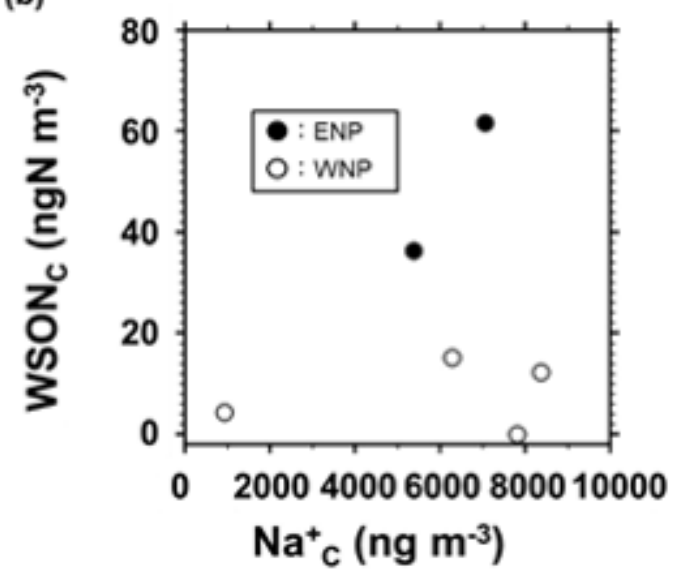

(d)

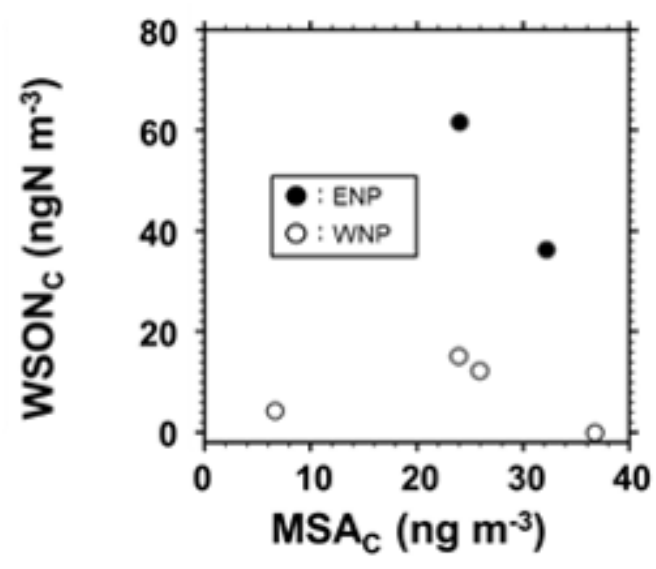

Figure 4 
Concentrations of WSON as functions of those of sodium (a, b) and MSA (c, d), where (a) and (c) are for the fine particles and (b) and (d) are for the coarse particles. Solid and open circles represent the data of the eastern North Pacific (ENP) and western North Pacific (WNP), respectively.

Figure 5

Longitudinal distributions of mass concentrations of (a) WSON $\mathrm{N}_{\mathrm{F}}$ and (b) WSON $\mathrm{N}_{\mathrm{C}}$, together with $\mathrm{N}_{2}$ fixation rate in the SSW samples during the entire cruise.

(a)

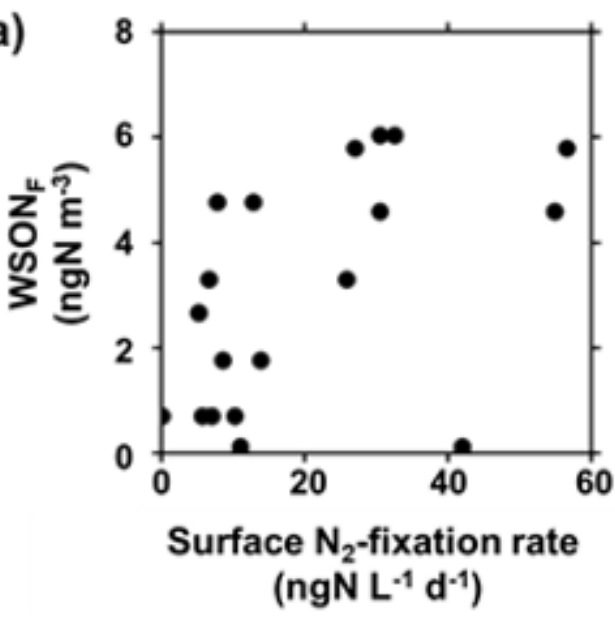

(b)

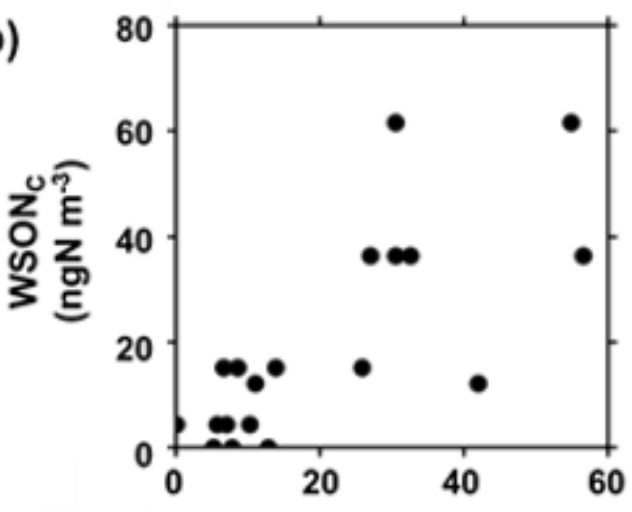

Surface $\mathrm{N}_{2}$-fixation rate

(ngN L-1 $\mathrm{d}^{-1}$ )

Figure 6

Mass concentrations of (a) WSON $\mathrm{N}_{\mathrm{F}}$ and (b) $W S O N_{C}$ as a function of $\mathrm{N}_{2}$-fixation rate in SSW. The data of $\mathrm{N}_{2}$-fixation rate in SSW was merged into the duration of each corresponding aerosol sampling. For each one aerosol sample, one or more corresponding measurement data of $\mathrm{N}_{2}$-fixation rate in SSW were obtained, so that the number of the data point in the panels is more than that of the aerosol samples.

\section{Supplementary Files}

This is a list of supplementary files associated with this preprint. Click to download.

- BGSupplement20220627.docx 